Original Research Paper

\title{
Analysis of Constituents and Bacteriostatic Activity of Essential Oil Extracted from Sea Buckthorn Seeds by Different Methods
}

\author{
${ }^{1}$ Hepeng Zhao, ${ }^{1}$ Fuyin Zhao, Qian Xiao, Xiudong Yang and *Hongli Zhou \\ School of Chemistry and Pharmaceutical Engineering, Jilin Institute of Chemical Technology, Jilin 132022, PR China
}

\begin{abstract}
Article history
Received: 17-03-2021

Revised: 28-04-2021

Accepted: 23-05-2021

Corresponding Author:

Hongli Zhou

School of Chemistry and Pharmaceutical Engineering, Jilin Institute of Chemical Technology, Jilin 132022, PR China

Email: zhouhongli@jlict.edu.cn

${ }^{1}$ These authors are joint first authors
\end{abstract}

\begin{abstract}
Sea buckthorn is a homologous plant listed in Chinese pharmacopoeia. The Essential Oils (EOs) of Sea Buckthorn Seeds (SBTS) are widely used in medicine and health products in China, Russia and other countries. The extraction methods of SBTS with advantages of low cost, high yield and high activity have attracted considerable attention. In this study, the extraction rate, chemical compositions and antibacterial activity of EOs from SBTS from Jilin Province extracted by Hydrodistillation (HD), Microwave-Assisted HD (MAHD) and Enzyme-Assisted HD (EAHD) were compared, so as to provide references for the preparation and application of EOs from SBTS. The results showed that the extraction rates of EOs from SBTS were $(0.457 \pm 0.062 \%)$ when extracted by EAHD. The extraction rate of EAHD was significantly higher, with values reaching 2.3 and 1.4 times that of HD and MAHD, respectively. A total of 18,26 and 26 volatile compounds were identified by Gas chromatography-mass spectrometer analysis. The three EOs were mainly composed of acid, ester and alkane and the acid component accounted for more than 50\% of total, with the highest acid proportion occupied by HD (63\%). The minimum inhibitory concentration of the EOs from SBTS extracted by HD, MAHD and EAHD against Bacillus subtilis, Bacillus pumilus and Staphylococcus aureus was determined simultaneously. The minimum inhibitory concentration of EOs from SBTS extracted by HD against Bacillus subtilis was $0.78 \mathrm{mg} / \mathrm{mL}$, which is better than EOs extracted by MAHD and EAHD and consistent with the positive control. The minimum inhibitory concentration of EOs extracted by the three extraction methods to Bacillus pumilus was 1.56 $\mathrm{mg} / \mathrm{mL}$, which was lower than the positive control. The minimum inhibitory concentration of EOs from SBTS against Staphylococcus aureus was 3.12 $\mathrm{mg} / \mathrm{mL}$, which was lower than that of the positive control but better than that of EOs extracted by MAHD and EAHD. Based on the experimental results, the different extraction methods have a great influence on the extraction rate, chemical composition and activity of EOs. Although the extraction rate of EOs from SBTS extracted by HD was lower, it had low cost, more active components and better activity. Thus, these EOs can be developed as a natural antibacterial agent in the future.
\end{abstract}

Keywords: Sea Buckthorn Seeds, Essential Oils, Chemical Composition, Antimicrobial Activity

\section{Introduction}

Sea buckthorn (Hippophae rhamnoides L.) is an ancient plant with modern value and it is widely distributed in Asia and Europe. Given its unique nutrition and biological activity, Sea buckthorn has been used as a kind of traditional medicine in Russia and China
(Marsiñach and Cuenca, 2019). Sea buckthorn, characterized by nitrogen fixation, cold resistance, salt and alkali resistance and wind and sand fixation, is a precious tree species for ecological forest construction (Fatima et al., 2012). Sea buckthorn fruit and Sea Buckthorn Seeds (SBTS) are rich in flavonoids, triterpenic acid, natural vitamins, Essential Oils (EOs), trace elements and other 
functional active ingredients beneficial to the human body. Triterpenes have an anti-inflammatory activity (Chernenko et al., 2004). Flavonoids are found in many parts of sea buckthorn, with leaves having the highest flavonoid cintents (Stobdan et al., 2013). The flavonoids in sea buckthorn have biological activities, including antiaging, anti-fatigue, anti-tumor and immunity enhancement (Stobdan et al., 2013; Li et al., 2018). As a medicinal food homologous plant, sea buckthorn fruit is also widely used in fruit juice, jam and other food fields (Wang, 2015).

EOs are the main active ingredient in SBTS. The EOs of SBTS mainly contain acids, esters, alkanes, etc. Yue et al. (2017) extracted EOs from SBTS from Yijun, Shaanxi Province through Hydrodistillation (HD); the main components of EOs of SBTS are n-hexadecanoic acid, dibutyl phthalate, oleic acid and other unsaturated fatty acids and they exhibit a good antibacterial activity. Punia and Kumari (2017) summarized that the EOs of SBTS mainly contain fatty acids such as $\alpha$-linolenic acid, palmitoleic acid and linoleic acid, which have antibacterial, antioxidant and anti-arteriosclerosis properties, increased activity of regenerative cell and other biological activities.

EOs are extracted through various way. Conventional HD, Microwave-Assisted HD (MAHD) and EnzymeAssisted HD (EAHD) are common extraction methods for EOs. HD is the most commonly used means for extracting EOs from natural plants. Its process, equipment, operation and other technologies are relatively mature and have low cost and the equipment and operation are relatively simple (Jiao et al., 2012; Wang et al., 2010). MAHD works by radiating microwave-emitting solvents through the cell wall to the inside of the cell. As the solvent and cell fluid absorb the microwave energy, the cell wall ruptures, freeing the active ingredients in the cell. MAHD has the advantages of short extraction time and high extraction rate (Wang et al., 2010; Golmakani and Rezaei, 2008). Enzymes can gradually degrade the cellulose-forming skeleton of the cell wall into glucose, destroy the skeleton structure of the cell wall and increase the dissolution of active components in cells. EAHD can decompose plant tissues gently, increase yield and extract active ingredients from plants to the maximum extent; thus, it has great application potential (Jiao et al., 2012).

To our knowledge, EOs from SBTS have been extensively studied, but no study reported about EOs from SBTS in Jilin. In addition, the preparation of EOs still presents challenges; HD exhibits disadvantages, such as long time, high energy consumption and low extraction rate (Della Porta et al., 1998; Chen et al., 2014). Related research has focused on the establishment of a high-efficiency, high-yield and high-activity extraction method for EOs from SBTS. Sea buckthorn in Jilin, China was used as the research object. The EOs of SBTS were extracted by HD, MAHD and EAHD. The
EOs of SBTS were extracted by HD, MAHD and EAHD. The constituents of the EOs were analyzed by Gas Chromatography-Mass Spectrometer (GC-MS). The antimicrobial activities of EOs extracted by three different extraction methods were studied by using Bacillus subtilis, Bacillus pumilus and Staphylococcus aureus and the effects of these methods on the EOs of SBTS were investigated. The present study provides a theoretical basis for the development of sea buckthorn-related products in Jilin, China.

\section{Materials and Methods}

\section{Materials and Reagents}

SBTS were produced from a new variety Changbai Mountain No. 27 in Seabuckthorn Planting Base, Jiaohe City, Jilin Province, China and authenticated by Prof. Guangshu Wang, School of Pharmaceutical Sciences, Jilin University, Changchun, China. The samples were dried in a cool, ventilated container and the dried samples were crushed to powder.

Cellulase was purchased from Shanghai Yuanye Biotechnology Co. Dichloromethane was purchased from Tianjin Damao Chemical Reagent Factory. The strains, including Bacillus subtilis ATCC 6633, Bacillus pumilus ATCC 700814 and Staphylococcus aureus ATCC 29213 were purchased from Beijing Yuding Xinjie Technology Co. All reagents used were of analytical reagent grade.

\section{Instruments}

A GC-MS equipment (Shimadzu, Kyoto, Japan) and microwave synthesis reaction station at atmospheric pressure (Shanghai Xinyi Microwave Chemical Technology Co.) were used.

\section{Culture of Strains}

Bacillus subtilis, Bacillus pumilus and Staphylococcus aureus were obtained from Beijing Yuding Xinjie Technology Co. and cultured. A total of $20 \mu \mathrm{L}$ microorganisms were absorbed by the micropipette and added to the corresponding medium. Before the bacteriostatic test, the three microorganisms were cultured for 24-48 $\mathrm{h}$ to ensure that they were active in their physiological period.

\section{Preparation of EOs}

Exactly $40 \mathrm{~g}$ SBTS powder and water were added to a $1000 \mathrm{~mL}$ round-bottom flask at a ratio of 1:15 and thoroughly mixed to prepare the extract. HD conditions: The above extracts were extracted by HD for $6 \mathrm{~h}$; MAHD conditions: The above extracts were extracted with microwave power of $600 \mathrm{~W}$ for $60 \mathrm{~min}$; EAHD conditions: The enzyme dosage was $0.77 \%$ SBTS and enzyme hydrolysis was conducted for $70 \mathrm{~min}$ at $55^{\circ} \mathrm{C}$, 
followed by extraction for $3 \mathrm{~h}$. According to the general rules of four parts of Chinese Pharmacopoeia (2015 edition) 2204, the EOs were determined by the first method. After the extraction, dichloromethane was used to extract the oil layer and methylene chloride was distilled by a rotary evaporator to obtain the EOs of SBTS. The EOs were transferred to a brown bottle and sealed. The bottled was stored at $4{ }^{\circ} \mathrm{C}$ for later use.

Equation (1) illustrates the formula used to calculate the extraction rate of EOs:

$$
\text { Extraction rate of EOs }=\left(m_{1} / m_{2}\right) \times 100 \%
$$

Where:

$m_{1}=$ The weight of EOs extracted from SBTS

$m_{2}=$ The sample weight of SBTS

\section{GC-MS Analysis}

The contents of EOs from SBTS were studied by GC-MS. The following equipment and conditions were used: The chromatographic conditions involved the Rxi 5MS capillary column $(30 \mathrm{~m}, 0.25 \mathrm{~mm}, 0.25$ $\mu \mathrm{m})$ with helium as carrier gas at $1 \mathrm{~mL} / \mathrm{min}$, sample volume $1.0 \mathrm{~L}$. The $\mathrm{GC}$ oven temperature was kept at $6^{\circ} \mathrm{C}$ for $6 \mathrm{~min}$, adjusted to $250^{\circ} \mathrm{C}$ at a rate of $3^{\circ} \mathrm{C} / \mathrm{min}$, then kept constant for $30 \mathrm{~min}$. The injection port temperature was $250^{\circ} \mathrm{C}$ and the column pressure was $49.5 \mathrm{kPa}$, For MS, an electron ionization iSource at a temperature of $230^{\circ} \mathrm{C}$ was used. The electron energy was $70 \mathrm{eV}$ and the scanning mass range was 40-500 $\mathrm{m} / \mathrm{z}$. The percent content of constituents was calculated automatically from peak areas of the total ion chromatogram. Constituents were identified from mass spectra and retention times using the NIST library.

The EOs extracted by the three methods were diluted 50 times with diethyl ether before the GC-MS analysis (Elkady and Ayoub, 2018).

Total Ion Current (TIC) was obtained by GC-MS in full scan mode. Each compound was determined by comparing the retention indices associated with the n-alkane mixture standard $\left(\mathrm{C}_{8}-\mathrm{C}_{40}\right)$ and their mass spectra with reference data in the MS database (NIST 05) (Tian et al., 2019).

\section{Bacteriostatic Activity}

The antibacterial activity of EOs from SBTS extracted by three different methods against Bacillus subtilis, Bacillus pumilus and Staphylococcus aureus was determined.

The minimum inhibitory concentration, defined as the minimum concentration that inhibits the growth of visible microorganisms, was detected by broth microdilution assay. The EO of SBTS were tested on different bacteria. In a 96-well plate, $180 \mu \mathrm{L}$ bacterial standard suspension $\left(10^{8} \mathrm{CFU} / \mathrm{mL}\right)$ and $20 \mu \mathrm{L}$ EO diluent were added to each well. In the first well, the concentration of EOs was $50 \mathrm{mg} / \mathrm{mL}$. The concentration of EOs in the following 10 wells was reduced by serial two-fold dilution. The EO dissolved in 20\% Dimethyl Sulfoxide (DMSO) and chloramphenicol (0.78-200 $\mathrm{mg} / \mathrm{mL}$ ) was the positive control and the $20 \%$ DMSO solution without EOs was the negative control. All assays were repeated thrice (Cui et al., 2018).

\section{Results}

\section{Extraction Rate of EOs}

Figure 1 shows the extraction rates of EOs extracted by HD, MAHD and EAHD. The extraction rates of EOs from SBTS obtained by HD $(0.195 \pm 0.051 \%)$, MAHD $(0.331 \pm 0.033 \%)$ and EAHD $(0.457 \pm 0.062 \%)$ were determined. The extraction rate of EAHD was 2.3 and 1.4 times higher than that of HD and MAHD, respectively. The high yield rates of EAHD and MAHD may be due to the capability of enzymes to decompose plant tissues to maximize the flow of EOs (Sharma et al., 2002). Microwave radiation causes a rapid rise in the internal temperature of the cell; as a result, the cell wall ruptures and the EOs are released from the cell (Farhat et al., 2011).

\section{Analysis of the Compositions of EOs of SBTS Extracted by Three Different Extraction Methods}

Quantification was expressed as a percentage of the peak area. The relative content of each component (\%) was calculated based on the peak area of GC. In terms of the TIC area, the EOs extracted by HD, MAHD and EAHD accounted for 91.78, 93.28 and $92.95 \%$ respectively. Table 1 shows the results.

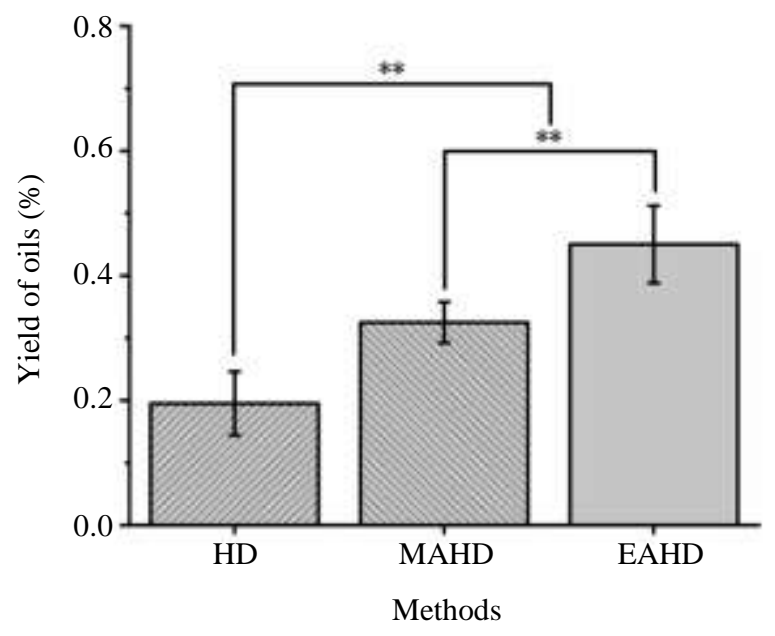

Fig. 1: Oils yield of SBTS extracted by different methods. $* * P<0.01$ compared with the HD 
Table 1: Composition of EOs extracted from SBTS by different extraction methods

\begin{tabular}{|c|c|c|c|c|c|c|}
\hline \multirow[b]{2}{*}{ No. } & \multirow[b]{2}{*}{ Compound } & \multirow[b]{2}{*}{$\begin{array}{l}\text { Molecular } \\
\text { formula }\end{array}$} & \multirow[b]{2}{*}{$\begin{array}{l}\text { Molecular } \\
\text { weight }\end{array}$} & \multicolumn{3}{|c|}{ Content, \% } \\
\hline & & & & HD & MAHD & EAHD \\
\hline 1 & 9-Hexadecenoic acid & $\mathrm{C}_{16} \mathrm{H}_{30} \mathrm{O}_{2}$ & 254 & 1.06 & 1.17 & 1 \\
\hline 2 & Palmitic acid & $\mathrm{C}_{18} \mathrm{H}_{36} \mathrm{O}_{2}$ & 256 & 12.84 & 14.05 & 4.6 \\
\hline 3 & Methyl 9-octadecynoate & $\mathrm{C}_{19} \mathrm{H}_{34} \mathrm{O}_{2}$ & 294 & 2.64 & & \\
\hline 4 & Hexadecanoic acid, butyl ester & $\mathrm{C}_{20} \mathrm{H}_{40} \mathrm{O}_{2}$ & 312 & & 1.9 & \\
\hline 5 & Linoleic acid & $\mathrm{C}_{20} \mathrm{H}_{36} \mathrm{O}_{2}$ & 280 & 17.92 & 17.68 & 18.28 \\
\hline 6 & Linolenic acid & $\mathrm{C}_{20} \mathrm{H}_{34} \mathrm{O}_{2}$ & 278 & 26.51 & 20.04 & 18.59 \\
\hline 7 & Stearic acid & $\mathrm{C}_{20} \mathrm{H}_{40} \mathrm{O}_{2}$ & 284 & 3.68 & 4.7 & 4.85 \\
\hline 8 & Heneicosane & $\mathrm{C}_{21} \mathrm{H}_{44}$ & 296 & & 0.93 & \\
\hline 9 & 1-Heneicosyl formate & $\mathrm{C}_{22} \mathrm{H}_{44} \mathrm{O}_{2}$ & 340 & & 2.8 & \\
\hline 10 & Oleic acid & $\mathrm{C}_{20} \mathrm{H}_{38} \mathrm{O}_{2}$ & 282 & & & 1.24 \\
\hline 11 & 4-Methyldocosane & $\mathrm{C}_{23} \mathrm{H}_{48}$ & 324 & & & 2.62 \\
\hline 12 & 11,14-Eicosadienoicacid, methyl ester & $\mathrm{C}_{21} \mathrm{H}_{38} \mathrm{O}_{2}$ & 322 & & & 1 \\
\hline 13 & 1-Heneicosanol,1-formate & $\mathrm{C}_{22} \mathrm{H}_{44} \mathrm{O}_{2}$ & 340 & & & 1.22 \\
\hline 14 & 5-Cyclohexylicosane & $\mathrm{C}_{26} \mathrm{H}_{52}$ & 364 & & & 1.86 \\
\hline 15 & Heptacosane & $\mathrm{C}_{26} \mathrm{H}_{52}$ & 380 & 2.98 & 2.97 & 3.66 \\
\hline 16 & $\begin{array}{l}\text { 9,12-Octadecadienoicacid }(9 Z, 12 Z)- \\
\text { 2,3-dihydroxypropyl ester }\end{array}$ & $\mathrm{C}_{21} \mathrm{H}_{38} \mathrm{O}_{4}$ & 354 & 1.3 & 1.28 & 1.47 \\
\hline 17 & Methyl (Z)-5,11,14,17-eicosatetraenoate & $\mathrm{C}_{21} \mathrm{H}_{34} \mathrm{O}_{2}$ & 318 & & & 4.93 \\
\hline 18 & $\begin{array}{l}\text { 9-[(Z)-2-[(1Z,3Z)-3-Hexenylidene }] \text { cyclopropylidene }] \\
\text { nonanoic acid 2-hydroxy-1-(hydroxymethyl)ethyl est }\end{array}$ & $\mathrm{C}_{21} \mathrm{H}_{36} \mathrm{O}_{4}$ & 352 & 2.44 & 1.01 & 1.26 \\
\hline 19 & Decyl octyl adipate & $\mathrm{C}_{24} \mathrm{H}_{46} \mathrm{O}_{4}$ & 398 & & 7.34 & \\
\hline 20 & 22-Tricosenoic acid & $\mathrm{C}_{23} \mathrm{H}_{44} \mathrm{O}_{2}$ & 352 & & & 3.69 \\
\hline 21 & (Z)-14-Tricosenyl formate & $\mathrm{C}_{24} \mathrm{H}_{46} \mathrm{O}_{2}$ & 366 & 3.52 & & \\
\hline 22 & Hexanedioic acid,1-decyl 6-octyl ester & $\mathrm{C}_{24} \mathrm{H}_{46} \mathrm{O}_{4}$ & 398 & 2.8 & 2.74 & 3.06 \\
\hline 23 & 2,6-Octadiene, 2,6-dimethyl- & $\mathrm{C}_{10} \mathrm{H}_{18}$ & 138 & & & 1.48 \\
\hline 24 & 9-Eicosene-1,20-diol,1,20-diacetate & $\mathrm{C}_{24} \mathrm{H}_{44} \mathrm{O}_{4}$ & 396 & 2.76 & & \\
\hline 25 & 1-Methyl-4-(1-methylethenyl) cyclohexanol & $\mathrm{C}_{10} \mathrm{H}_{18} \mathrm{O}$ & 154 & & & 1.32 \\
\hline 26 & 2,2'-Methylenebis(6-tert-butyl-4-methylphenol) & $\mathrm{C}_{23} \mathrm{H}_{32} \mathrm{O}_{2}$ & 340 & 2.45 & 0.9 & 4.27 \\
\hline 27 & Stigmastane-3,6-dione,(5a)- & $\mathrm{C}_{29} \mathrm{H}_{48} \mathrm{O}_{2}$ & 428 & & 1.12 & \\
\hline 28 & Cyclotetracosane & $\mathrm{C}_{23} \mathrm{H}_{32} \mathrm{O}_{2}$ & 336 & & & 2.1 \\
\hline 29 & Dotriacontane & $\mathrm{C}_{32} \mathrm{H}_{66}$ & 450 & 1.31 & 1.07 & 2.19 \\
\hline 30 & 1-bromotriacontane & $\mathrm{C}_{30} \mathrm{H}_{61} \mathrm{Br}$ & 501 & & 1.08 & \\
\hline 31 & di-n-Decyl phthalate & $\mathrm{C}_{28} \mathrm{H}_{46} \mathrm{O}_{4}$ & 446 & & 1.53 & \\
\hline 32 & Tetratriacontane & $\mathrm{C}_{34} \mathrm{H}_{70}$ & 478 & & 1.05 & \\
\hline 33 & Pentatriacontane & $\mathrm{C}_{35} \mathrm{H}_{72}$ & 492 & & 1.56 & \\
\hline 34 & 2,5-Furandione,3-(2-dodecen-1-yl)dihydro- & $\mathrm{C}_{16} \mathrm{H}_{26} \mathrm{O}_{3}$ & 266 & & & 1.85 \\
\hline 35 & 4-Methyl-4-hydroxycyclohexanone & $\mathrm{C}_{15} \mathrm{H}_{30} \mathrm{O}$ & 226 & & & 1.23 \\
\hline 36 & 9-Octadecenoic acid(9Z)-, tetradecyl ester & $\mathrm{C}_{32} \mathrm{H}_{62} \mathrm{O}_{2}$ & 478 & 2.08 & & \\
\hline 37 & Hexatriacontane & $\mathrm{C}_{36} \mathrm{H}_{74}$ & 506 & 1.14 & 1.28 & \\
\hline 38 & 1,2-Benzenedicarboxylic acid, ditridecyl ester & $\mathrm{C}_{24} \mathrm{H}_{38} \mathrm{O}_{4}$ & 530 & & 1.2 & \\
\hline 39 & 17-Pentatriacontene & $\mathrm{C}_{35} \mathrm{H}_{70}$ & 490 & 1.88 & & 2.48 \\
\hline 40 & tetracontane & $\mathrm{C}_{40} \mathrm{H}_{82}$ & 563 & 1.67 & 2.71 & 1.67 \\
\hline 41 & Dotetracontane & $\mathrm{C}_{42} \mathrm{H}_{86}$ & 591 & & 0.9 & \\
\hline 42 & Tritetracontane & $\mathrm{C}_{43} \mathrm{H}_{88}$ & 618 & & 1.29 & \\
\hline 43 & Hexadecanoic acid, 1,1'-(2-hydroxy- 1,3-propanediyl) ester & $\mathrm{C}_{35} \mathrm{H}_{68} \mathrm{O}_{5}$ & 568 & & & 1.57 \\
\hline 44 & 1-Hentetracontanol & $\mathrm{C}_{41} \mathrm{H}_{84} \mathrm{O}$ & 593 & & 0.88 & \\
\hline
\end{tabular}

Table 2: Composition of EOs extracted from SBTS by different extraction methods

\begin{tabular}{llccccc}
\hline & Acids $(\%)$ & Esters $(\%)$ & Alkane $(\%)$ & Alcohols & Others $(\%)$ & Total $(\%)$ \\
\hline HD & 65.81 & 6.02 & 8.98 & - & 10.97 & 91.78 \\
MAHD & 57.56 & 11.35 & 14.84 & 0.88 & 8.57 & 93.28 \\
EAHD & 54.99 & 10.23 & 18.06 & 1.32 & 8.35 & 92.95 \\
\hline
\end{tabular}

As presented in Table 2, the EOs extracted from SBTS by HD, EMHD and MAHD were mainly composed of fatty acids, esters and alkanes, among which fatty acids are the most common, with the contents of $65.81 \%$ (HD), $57.56 \%$ (MAHD) and $54.99 \%$ (EMHD), respectively. Compared with the findings of 
Yue et al., the content of fatty acids in the EOs extracted from SBTS increased, which might be caused by different species and growing environment of sea buckthorn. Wen et al. (2018) compared the chemical constituents of the EOs of Saussurea sinensis from different production areas and observed that due to the influence of temperature, sunshine, latitude, altitude, soil, vegetation, precipitation distribution and cultivation technology level in different regions, the chemical constituents of EOs differed to a certain extent. The fatty acids extracted by the three methods were the same and mainly included linoleic acid (17.92, 17.68 and 18.28\%), linolenic acid (26.51, 20.04 and $18.59 \%)$, palmitic acid $(12.84,14.05$ and $4.06 \%)$. The extraction mechanism of different extraction methods may be the reason for the different fatty acid contents. Xiang et al. (2010) analyzed the EOs of propolis by HD and supercritical carbon dioxide extraction and the results showed significant differences in the EOs components obtained by these extraction methods. Thus, in industrial production, we should not only pay attention to the extraction rate but also the importance of component contents.

Fatty acids have various physiological functions. Linoleic and linolenic acids are essential fatty acids that cannot be synthesized by themselves and can only be obtained through diet (Marsiñach and Cuenca, 2019). Linolenic acid is a physiological component of the cell membrane and mitochondrial membrane and is involved in cell transport and neuronal signal transmission (Zielińska and Nowak, 2014). This compound has an antihypertensive effect on blood pressure. Linoleic acid is the most abundant polyunsaturated fatty acid in human skin. A lack of linoleic acid in diet can lead to typical squamous skin disease and excessive epidermal water loss (Ziboh et al., 2000). Linolenic and linolenic acids play an important role in bone development (Griel et al., 2007; Lavado-García et al., 2018).

\section{Antibacterial Activity of EOs from SBTS Extracted by Three Different Extraction Methods}

As shown in Table 3, the minimum inhibitory concentration of EOs from SBTS extracted by HD against Bacillus subtilis was $0.78 \mathrm{mg} / \mathrm{mL}$, which was better than and half that of the minimum inhibitory concentration of EOs from SBTS extracted by MAHD and EAHD. This result is also consistent with the positive control. The minimum inhibitory concentration of EOs from SBTS extracted by the three methods to Bacillus pumilus was $1.56 \mathrm{mg} / \mathrm{mL}$, which was less than that of the positive control and twice of its minimum inhibitory concentration. The minimum inhibitory concentration of EOs from SBTS extracted by HD against Staphylococcus aureus was $3.12 \mathrm{mg} / \mathrm{mL}$, which was lower than that of the positive control but better than that of EOs extracted by MAHD and EAHD.
Table 3: The minimum inhibitory concentration and positive control of EOs from SBTS against different bacteria (mean value, $\mathrm{mg} / \mathrm{mL}$ )

\begin{tabular}{llll}
\hline & $\begin{array}{l}\text { Bacillus } \\
\text { subtilis }\end{array}$ & $\begin{array}{l}\text { Bacillus } \\
\text { pumilus }\end{array}$ & $\begin{array}{l}\text { Staphylococcus } \\
\text { aureus }\end{array}$ \\
\hline HD & 0.78 & 1.56 & 3.12 \\
MAHD & 1.56 & 1.56 & 6.25 \\
EAHD & 1.56 & 1.56 & 6.25 \\
Chloramphenicol & 0.78 & 0.78 & 0.78 \\
\hline
\end{tabular}

The antibacterial effect of EOs from SBTS may be related to their rich free fatty acids, several of which can kill or inhibit the growth of bacteria. The main targets of free fatty acids are cell membranes, where they disrupt electron transport chains and oxidative phosphorylation. In addition to interfering with cell energy production, free fatty acids may inhibit enzyme activity, damage nutrient absorption, produce peroxidation and autooxidation degradation products, or directly lyse bacterial cells (Desbois and Smith, 2010). Linoleic and linolenic acids have good bacteriostatic effects on certain strains (Amgalanbaatar et al., 2014; Jung et al., 2015; Jang et al., 2016).

\section{Conclusion}

The EOs from SBTS were extracted by HD, MAHD and EAHD. The effects of these different extraction methods on the extraction rate, composition and antibacterial activity of the EOs from SBTS were studied. The results showed that the extraction yield of EAHD was the highest and the extraction yields of MAHD and EAHD were significantly higher than that of HD. A total of 18, 26 and 26 chemical components were identified from the EOs extracted by HD, MAHD and EAHD, respectively. The three extracts all contained acids, esters, alkanes and other compounds, but the contents of components were significantly different. The EOs extracted by the three methods had antibacterial effect on Bacillus subtilis, Bacillus pumilus and Staphylococcus aureus. The antibacterial effect of the EOs extracted by microwave and enzyme-assisted extraction was lower than that of the positive control. Compared with those obtained by the other methods, the EOs extracted by HD had a better inhibitory effect on Bacillus subtilis, consistent with the positive control. The antibacterial effect of EOs extracted by HD on Staphylococcus aureus was better than that of the EOs extracted by the other two methods but is inferior to that of the positive control. Bacillus subtilis, Bacillus pumilus and Staphylococcus aureus are representative Gram-positive bacteria, especially Staphylococcus aureus. Staphylococcus aureus is one of the most important pathogenic bacteria in humans and it can cause numerous serious infections (Tomlinson et al., 2012; 
Grundmann et al., 2006). EOs extracted from SBTS have antibacterial effect on Staphylococcus aureus, which indicates that they have potential to be developed as nature-based antibacterial agents. In conclusion, different extraction areas and extraction methods have great effects on the extraction rate, components and antibacterial activity of volatile oils from SBTS. Despite the assumption that high yield and good activity are consistent, the experiment showed that the extraction yield of SBTS oil obtained by the three methods is not necessarily related to antimicrobial activity. In the future, when the EOs from SBTS are developed and utilized in the fields of medicine and food, the extraction method can be determined based on the level analysis of the target composition and extraction rate to improve the EOs of SBTS as antibacterial agents, promote epithelial tissue regeneration, burn and reduce blood lipids and exert an anti-tumor effect (Du et al., 2004; Korneyev, 2003).

\section{Acknowledgement}

This investigation was supported by the programs of Science and Technology Research Project of Jilin Institute of Chemical Technology (Grant No. 2018075), Jilin College Students Innovation and Entrepreneurship Training project.

\section{Author's Contributions}

Hepeng Zhao and Fuyin Zhao: Extracted and analyzed the constituents of EOs from SBTS and studied their antibacterial activity.

Qian Xiao: Revised and proofread the thesis.

Hongli Zhou and Xiudong Yang: Guided the design route and provided experimental guidance for this manuscript.

\section{Ethics}

This article is original and contains unpublished material. The corresponding author confirms that all of the other authors have read and approved the manuscript and no ethical issues involved.

\section{References}

Amgalanbaatar, A., Shimomura, H., Hosoda, K., Hayashi, S., Yokota, K., \& Hirai, Y. (2014). Antibacterial activity of a novel synthetic progesterone species carrying a linoleic acid molecule against Helicobacter pylori and the hormonal effect of its steroid on a murine macrophage-like cell line. The Journal of Steroid Biochemistry and Molecular Biology, 140, 17-25. https://doi.org/10.1016/j.jsbmb.2013.10.023
Chen, Z., Mei, X., Jin, Y., Kim, E. H., Yang, Z., \& Tu, Y. (2014). Optimisation of supercritical carbon dioxide extraction of essential oil of flowers of tea (Camellia sinensis L.) plants and its antioxidative activity. Journal of the Science of Food and Agriculture, 94(2), 316-321.

https://doi.org/10.1002/jsfa.6260

Chernenko, T. V., Ul'chenko, N. T., \& Glushenkova, A. I. (2004). Fruits of two seabuckthorn varieties. Chemistry of Natural Compounds, 40(6), 529-531. https://doi.org/10.1007/s10600-005-0028-8

Cui, H., Pan, H. W., Wang, P. H., Yang, X. D., Zhai, W. C., Dong, Y., \& Zhou, H. L. (2018). Essential oils from Carex meyeriana Kunth: Optimization of hydrodistillation extraction by response surface methodology and evaluation of its antioxidant and antimicrobial activities. Industrial Crops and Products, 124, 669-676. https://doi.org/10.1016/j.indcrop.2018.08.041

Della Porta, G., Taddeo, R., D'Urso, E., \& Reverchon, E. (1998). Isolation of clove bud and star anise essential oil by supercritical CO2extraction. LWTFood Science and Technology, 31(5), 454-460. https://doi.org/10.1006/fstl.1998.0381

Desbois, A. P., \& Smith, V. J. (2010). Antibacterial free fatty acids: activities, mechanisms of action and biotechnological potential. Applied Microbiology and Biotechnology, 85(6), 1629-1642. https://doi.org/10.1007/s00253-009-2355-3

Du, X. M., Wang, S. Y., Zhang, Z. C., Wang, J., \& Xing, G. L. (2004). Seabuckthorn seed oil in prevention of lifestyle-related disease. CNKI.

http://en.cnki.com.cn/Article_en/CJFDTotalSACH200404013.htm

Elkady, W. M., \& Ayoub, I. M. (2018). Chemical profiling and antiproliferative effect of essential oils of two Araucaria species cultivated in Egypt. Industrial Crops and Products, 118, 188-195. https://doi.org/10.1016/j.indcrop.2018.03.051

Farhat, A., Fabiano-Tixier, A. S., El Maataoui, M., Maingonnat, J. F., Romdhane, M., \& Chemat, F. (2011). Microwave steam diffusion for extraction of essential oil from orange peel: kinetic data, extract's global yield and mechanism. Food Chemistry, 125(1), 255-261.

https://doi.org/10.1016/j.foodchem.2010.07.110

Fatima, T., Snyder, C. L., Schroeder, W. R., Cram, D., Datla, R., Wishart, D., ... \& Krishna, P. (2012). Fatty acid composition of developing sea buckthorn (Hippophae rhamnoides L.) berry and the transcriptome of the mature seed. PloS One, 7(4), e34099. https://doi.org/10.1371/journal.pone. 0034099 
Golmakani, M. T., \& Rezaei, K. (2008). Microwave-assisted hydrodistillation of essential oil from Zataria multiflora Boiss. European Journal of Lipid Science and Technology, 110(5), 448-454. https://doi.org/10.1002/ejlt.200700239

Griel, A. E., Kris-Etherton, P. M., Hilpert, K. F., Zhao, G., West, S. G., \& Corwin, R. L. (2007). An increase in dietary n-3 fatty acids decreases a marker of bone resorption in humans. Nutrition Journal, 6(1), 1-8. https://doi.org/10.1186/1475-2891-6-2

Grundmann, H., Aires-de-Sousa, M., Boyce, J., \& Tiemersma, E. (2006). Emergence and resurgence of meticillin-resistant Staphylococcus aureus as a public-health threat. The lancet, 368(9538), 874-885. https://doi.org/10.1016/S0140-6736(06)68853-3

Jang, H., Makita, Y., Jung, K., Ishizaka, S., Karasawa, K., Oida, K., ... \& Tanaka, A. (2016). Linoleic acid salt with ultrapure soft water as an antibacterial combination against dermato-pathogenic Staphylococcus spp. Journal of Applied Microbiology, 120(2), 280-288. https://doi.org/10.1111/jam.13012

Jiao, J., Fu, Y. J., Zu, Y. G., Luo, M., Wang, W., Zhang, L., \& Li, J. (2012). Enzyme-assisted microwave hydro-distillation essential oil from Fructus forsythia, chemical constituents and its antimicrobial and antioxidant activities. Food Chemistry, 134(1), 235-243. https://doi.org/10.1016/j.foodchem.2012.02.114

Jung, S. W., Thamphiwatana, S., Zhang, L., \& Obonyo, M. (2015). Mechanism of antibacterial activity of liposomal linolenic acid against Helicobacter pylori. PloS One, 10(3), e0116519.

https://doi.org/10.1371/journal.pone.0116519

Korneyev, A. Y. (2003). U.S. Patent No. 6,576,269. Washington, DC: U.S. Patent and Trademark Office. https://patents.google.com/patent/US6576269B1/en

Lavado-García, J., Roncero-Martin, R., Moran, J. M., Pedrera-Canal, M., Aliaga, I., Leal-Hernandez, O., .. \& Canal-Macias, M. L. (2018). Long-chain omega-3 polyunsaturated fatty acid dietary intake is positively associated with bone mineral density in normal and osteopenic Spanish women. PloS One, 13(1), e0190539.

https://doi.org/10.1371/journal.pone.0190539

Li, C., Zhang, J., Zhao, C., Yang, L., Zhao, W., Jiang, H., ... \& Guan, J. (2018). Separation of the main flavonoids and essential oil from seabuckthorn leaves by ultrasonic/microwave-assisted simultaneous distillation extraction. Royal Society Open Science, 5(7), 180133.

https://doi.org/10.1098/rsos.18 0133
Marsiñach, M. S., \& Cuenca, A. P. (2019). The impact of sea buckthorn oil fatty acids on human health. Lipids in Health and Disease, 18(1), 1-11. https://doi.org/10.1186/s12944-019-1065-9

Punia, D., \& Kumari, N. (2017). Potential health benefits of Sea buckthorn oil-A review. Agricultural Reviews, 38(3). https://doi.org/10.18805/ag.v38i03.8984

Sharma, A., Khare, S. K., \& Gupta, M. N. (2002). Enzyme-assisted aqueous extraction of peanut oil. Journal of the American Oil Chemists' Society, 79(3), 215-218. https://doi.org/10.1007/s11746-002-0463-0

Stobdan, T., Korekar, G., \& B Srivastava, R. (2013). Nutritional attributes and health application of seabuckthorn (Hippophae rhamnoides L.)-A review. Current Nutrition \& Food Science, 9(2), 151-165. https://doi.org/10.2174/1573401311309020008

Tian, H., Zhao, H., Zhou, H., \& Zhang, Y. (2019). Chemical composition and antimicrobial activity of the essential oil from the aerial part of Dictamnus dasycarpus Turcz. Industrial Crops and Products, 140, 111713. https://doi.org/10.1016/j.indcrop.2019.111713

Tomlinson, K. L., Lung, T. W. F., Dach, F., Annavajhala, M. K., Gabryszewski, S. J., Groves, R. A., ... \& Riquelme, S. A. (2021). Staphylococcus aureus induces an itaconate-dominated immunometabolic response that drives biofilm formation. Nature Communications, 12(1), 1-13. https://doi.org/10.1038/S41467-021-21718-Y.

Wang, H. W., Liu, Y. Q., Wei, S. L., Yan, Z. J., \& Lu, K. (2010). Comparison of microwave-assisted and conventional hydrodistillation in the extraction of essential oils from mango (Mangifera indica L.) flowers. Molecules, 15(11), 7715-7723. https://doi.org/10.3390/molecules 15117715

Wang, Y. (2015). The Chinese pharmacopoeia[J]. China Standardization, 04, 132-135.

Wen, X., Wu, D., Li, J., Fu, C., Wang, W., \& Wang, Y. (2018). Compounds Analysis of Different Producing Areas from Essential Oil of Chrysanthemum. Northern Horticulture, 2018, 16. http://en.cnki.com.cn/Article_en/CJFDTotalBFYY201816027.htm

Xiang, X. U., Dong, J., \& Ding, X. Y. (2010). Propolis Essential Oil Extracted by Different Methods: Chemical Composition Analysis and Antibacterial Activity Evaluation[J]. Food Science. (in Chinese) http://en.cnki.com.cn/Article_en/CJFDTOTALSPKX201003012.htm 
Yue, X. F., Shang, X., Zhang, Z. J., \& Zhang, Y. N. (2017). Phytochemical composition and antibacterial activity of the essential oils from different parts of sea buckthorn (Hippophae rhamnoides L.). Journal of Food and Drug Analysis, 25(2), 327-332. https://doi.org/10.1016/j.jfda.2016.10.010

Ziboh, V. A., Miller, C. C., \& Cho, Y. (2000). Metabolism of polyunsaturated fatty acids by skin epidermal enzymes: generation of antiinflammatory and antiproliferative metabolites. The American Journal of Clinical Nutrition, 71(1), 361s-366s. https://doi.org/10.1017/S0029665100000185
Zielińska, A., \& Nowak, I. (2014). Fatty acids in vegetable oils and their importance in cosmetic industry. CHEMIK Nauka-Technika-Rynek, 68(2), 103-110.

https://www.researchgate.net/publication/286712435 Fatty acids in vegetable oils and their importance in cosmetic industry 